\title{
LOS OCHENTA AÑOS DE EDMUNDO O'GORMAN
}

\author{
Jorge Alberto Manrioue
}

Edmundo O'Gorman cumplió 80 años en noviembre de 1986. Su trayectoria como historiador ha ocupado la escena mexicana desde 1937. Al cumplitse sus 80 años se acabalan, punto menos que, sus 50 años de tareas históricas.

La presencia de O'Gorman en la historia mexicana no toma, sin embargo, su importancia de su larga persistencia (aunque ésta también sea notable) sino del carácter innovador y rebelde, a la búsqueda de nuevos caminos, que roturó desde el inicio y que ha seguido desbrozando hasta sus libros más recientes.

La ya temprana gran aportación suya, que le valió, entre disputas, polémicas y desaires, un reconocimiento inicial, fue la tarea a la que se dio, de examinar las cuestiones históricas desde una perspectiva filosófica. Formado inicialmente como abogado, antes de ser tocado por la tentación histórica ya había probado el vino de la filosofía. El derecho, disciplina de la razón rigurosa, por definición, y la filosofía — la razón imaginativa- fueron sus dos pertrechos para acercarse a la historia.

Para la cuarta década de este siglo, cuando O'Gorman entra a la historia con su Breve historia de las divisiones territoriales. . . de 1937 y su ingreso como subdirector al Archivo General de la Nación en 1938, la historia que se cultivaba en México, cualesquieran que fueran sus cualidades, era una desinencia del positivismo: la historia como ciencia, la idea de que existe una verdad histórica única y definitiva, que sólo basta perseguir tenazmente para alcanzarla; el desprecio de las fuentes secundarias en favor de las llamadas "primarias"; la idea de acumulación que tiende y se acerca al conocimiento completo; el posponer toda interpretación consciente hasta no llegar a ese inalcanzable pero supuesto conocimiento...

Frente a ello O'Gorman, arropado en la filosofía espiritualista de Antonio Caso, nutrido por otra parte de Kant y Hegel, enriquecido por la lectura de Ortega y Gasset y su vitalismo, y más tarde abonado por el contacto de José Gaos y el conocimiento de Heidegger y el existencialismo, enfrenta las cuestiones históricas de una manera totalmente novedosa. A partir de ese pertrecho va elaborando a vueltas su propio original pensamiento histórico. Como pensador capaz de elaborar una teoría personal sobre la historia, no creo que tenga parangón en lengua española en este 
siglo; y si en el mundo no ha tenido quizá el reconocimiento que le cotresponde, cosas son de la marginalidad de México y de la lengua española en el concierto de las naciones...

Una primera peculiaridad del pensamiento histórico de O'Gorman es que - siendo, como no puede no ser, filosófico - está desarrollado a partir de la historia, y no sólo a partir de la filosofía: tiene pues un fundamento práctico del que suelen carecer las filosofías de la historia. El soponcio ante las nuevas visiones propuestas por O'Gorman y el desabrimiento de las polémicas subsiguientes hicieron que se le acusara de ser "filósofo" -y de tanto en tanto, hasta las disputas más recientes, se reitera la acusación. Como si fuera agravio ser filósofo. No se necesita mucha perspicacia para comprender que detrás de la susodicha acusación se esconde otra, tácita: no es historiador, no sabe historia. El larguísimo trabajo de O'Gorman a través de cincuenta años, su prolijo hurgar de datos, amén del incansable y fatigoso manejo acucioso de fuentes y documentos son un mentís sobrado a la insidiosa insinuación.

Dos obras tempranas, capitales sin embargo, afincan los desarrollos posteriores de su pensamiento. Crisis y porvenir de la ciencia histórica, de 1947, presenta el planteamiento teorético, no obstante apoyado en el análisis de hechos concretos y de historiadores que fueron de carne y hueso. Idea del descubrimiento de América..., de 1951, implica la aplicación de las ideas al asunto concreto del hecho llamado "descubrimiento". En ambos están planteadas las cuestiones fundamentales: no hay quehacer histórico verdadero que no se plantee en cada cuestión el concepto de verdad histórica, que no analice la contextura del hecho histórico; la interpretación histórica no es una tara sino una necesidad, y por ella se valida el trabajo del historiador; la realidad histórica como tal no existe sino en nuestra conciencia; el pasado ni se acepta ni se rechaza, simplemente nos constituye; la contingencia es un elemento histórico insoslayable; los héroes son gente de carne y hueso... y suma y sigue.

La perseguida preocupación por la historia americana, a través de los años y de libros y artículos tiene una primera culminación en La invención de América... (de 1958). Libro central en la historiografía americana, producida o no en el continente, y capital como interpretación, a partir del hecho americano, de la cultura de Occidente. Creo que las mayores aportaciones que América -especialmente la nuestra-- ha dado al pensamiento del mundo son las que resultan de nuestra propia inagotable pregunta sobre el ser americano: La invención ocupa en esta historia del pensamiento un sitio privilegiado. 
Por su parte, el otro gran cauce del trabajo de O'Gorman, sus estudios sobre tema mexicano, que se inician con las publicaciones del Boletín del Archivo General de la Nación, en 1938, siguen con su Fray Servando de 1945 y continúan con numerosos libros y artículos, tienen tres puntos culminantes: Meditaciones sobre el criollismo, de 1970; México: el trauma de su historia, de 1977, y Destierro de sombras, de 1986. El lema que ampara a la segunda de estas obras es válido para las tres: ducit amor patriae. El primero es el estudio sobre lo que llamaríamos la "personalidad ontológica" del mexicano rastreadas en los siglos anteriores a la Independencia. El segundo es su gran ensayo personal acerca de las contradicciones de la historia mexicana, que recae necesariamente sobre las características del ser mexicano como nación; el tercero es el acucioso examen (precedido de Mier, el heterodoxo guadalupano) referido a la presencia e historiografía de la imagen de la Virgen de Guadalupe en México.

Basta referirse tan someramente como aqui lo he hecho a la obra de O'Gorman para entender el gran peso que éste ha tenido en la formación de ya numerosas generaciones de historiadores. Pero debe recordarse también en ese sentido su cátedra en la Facultad de Filosofía y Letras, reconocida por brillante y rigurosa, a la que se asistía con la reverencia de una liturgia y la animación de un espectáculo; o su seminario (que llamábamos "seminario de seminarios" porque en un tiempo asistíamos no sólo profesores, sino que llegó a reunir tres directores simultáneamente); y desde luego sus conferencias, tan espectaculares como enjundiosas...

No sólo ahí ha estado la enseñanza de O'Gorman, sino en lo que llamaría sus actitudes morales, tanto para enfrentarse a los análisis históricos (hace diez años, en ocasión de celebrar sus 70 años, destacaba yo su actitud inconforme, de duda perenne), como para defender sus posturas en polémicas que han sido y son famosas ("león viejo, tiene usted la melena encanecida pero la zarpa todavía rápida y temible").

La obra de O'Gorman lo ha hecho merecedor de distinciones anejas a una personalidad académica como la suya (si bien su carácter polémico ha hecho que se le regatearan algunas, como El Colegio Nacional) : miembro de número de las academias de la Historia y de la Lengua, profesor emérito de la Universidad, Premio Nacional de Letras...

La cercanía a su padre, Cecil Crawford O'Gorman, pintor más que aficionado (quien le hizo dos magníficos retratos), amante de los objetos bellos, conocedor de pintura antigua; su temprana amistad con Justino Fernández, con quien mantuvo siempre una relación fraternal, con Manuel Toussaint, con Francisco de la Maza y con otros historiadores del arte; su propio cultivo de las artes, ya como arquitecto de sus propias casas, yá 
como pintor; todo ello hizo que O’Gorman se acercara más de una vez a las disciplinas que se cultivan en este Instituto de Investigaciones Estéticas. Colaboró con Toussaint en la recopilación de las fuentes para la historia de la litografía en México y escribió un ensayo que sigue siendo piedra miliar en las interpretaciones del arte prehispánico: "El arte o de la monstruosidad" (1940). Fue por muchos años miembro de la comisión dictaminadora del Instituto, y éste se honra en tenerlo como miembro honorario. De muy diversas formas ha sido el consejero respetado y el defensor de nuestra comunidad académica.

El Instituto de Investigaciones Estéticas celebra con toda la comunidad académica, pero por sus propios títulos, el octagésimo aniversario de don Edmundo O’Gorman: ¡Víctor! 